\title{
Salient Features of the Constitutions of Nepal and India: A Comparative Observation
}

\author{
Dilli Raj Gautam ${ }^{1}$
}

\begin{abstract}
While comparing the Constitution of Nepal 2015 and the Constitution of India 1950 the paper comparatively analyses the major issues such as citizenship, inclusiveness, fundamental rights and independence of judiciary. Both constitutions are committed to socialism based on democratic norms and values, including people's competitive multiparty democratic system of governance, civil liberties, fundamental rights, federal republic, secularism, adult franchise, periodic elections, full freedom of the press, and independent, impartial, competent and free judiciary and concept of the rule of law. This qualitative research article observes the salient features of the constitution of Nepal and India in descriptive and analytical order with comparative methodology.
\end{abstract}

Keywords: Constitution, Preamble, Provision, Fundamental Rights, Parliamentary, Sovereignty

\section{Introduction}

While observing historical facts, there are deep-rooted cultural linkages between Nepal and India. Being neighboring countries, they have a long history of common religious, linguistic and cultural identities. Social and cultural ties have been enhanced by the open border with no restrictions on the movement of the people on either side. India has long enjoyed a significant voice in Nepali politics (Kochhar and Jaiswal, 2016,P.15). Nepal from the despotic Rana Rule and India from the British colony became independent in the 1950s; Nepal in 1951 and India in 1947. Then only, these countries started constitution building process.

India completed her campaign within two and half years' of constituent assembly and promulgated the new constitution on $26^{\text {th }}$ Jan 1950, and proclaimed her a sovereign socialist secular democratic republic (Choudhary,Khosla and Mehta 2016, PP. 38-46). Comparatively Nepal's constitution building process took a long course. It started in 1948 and accomplished in 2015. The recent Constitution of Nepal 2015 (2072) is the seventh constitution. This is the first constitution made

1 Mr. Gautam is a lecturer of Political Science at Dhaulagiri Multiple Campus, TU, Baglung. 
and adopted by the Constituent Assembly (CA) which was specifically elected for this purpose and was proclaimed by the President of Nepal on September 20, 2015 (Asoj 3, 2072) (Bhandari, 2016, P.1). Constitutions of Nepal and India both are from the same philosophical and social background embracing liberalism and socialism, even though they have some distinct differences. This article seeks to reveal the distinct features of similarities and differences of the two constitutions.

\section{Salient Features of the Constitution of India}

The constitution of India is the largest written constitution in the world. It provides a mixture of federalism and Unitarianism, and flexibility and rigidity. Since its promulgation on $26^{\text {th }}$ January 1950 , it has been successfully guiding the path and progress of India (Kapur and Mishra, 2012, PP. 6-91).

\section{1) Written and Longest Constitution}

India's constitution is a written document incorporating the constitutional law of the country. It was fully debated and duly enacted in the Constituent Assembly. It consists of 395 articles divided into 22 parts with 12 schedules and 94 constitutional amendments. It is a constitution of both the centre and states of Indian union. It is longest in the world.

\section{2) Enacted Constitution}

Indian constitution is made by the people of India through the Constituent Assembly in December 1946. Its first session was held on $9^{\text {th }}$ December, 1946. It passed the objective Resolution on 22 January, 1947. Then after it initiated the process of constitution making in the right earnest and was in a position to finally pass and adopt the constitution on $26^{\text {th }}$ November 1949 . The constitution became fully operational on 26 January 1950.

\section{3) Preamble of the Constitution}

The Preamble to the Constitution of India is a 'well drafted' document which states the philosophy of the constitution. It declares India to be a sovereign socialist secular democratic republic and a welfare state, committed to secure justice liberty and equality for promoting fraternity and dignity of the individual and unity and integrity of the nation (Chakrabarty, 2017: P.86).

\section{4) Declaration of a Democratic Socialist State}

Although right from the very beginning, India's constitution fully reflected the spirit of democratic socialism, it was only in 1976 that the preamble was amended 
to include the term socialism (Sharma, 2017, p. 52). It is now regarded as a prime feature of India. India's constitution is committed to secure social, economic and political justice for its entire people by ending all forms of exploitation and by securing equitable distribution of income, resources and wealth. This is to be secured by peaceful, constitutional and democratic means (Mellalli, 2015:P.22).

People of India enjoy equal political rights and participate in the political phenomena. They elect their government. Periodic free and fair elections are held for electing governments for all its activities, the government of India is responsible for her people. People remain powerful.

The Constitution of India declared state secular, detaching from religious dogmas by forty- second amendment further, Indian secularism guarantees equal freedom to all religions. It grants the right to religious freedom to all the citizens (Ibid: P.23).

\section{5) Republic State}

The preamble of the constitution declares India to be a republic. It has an elected head of the state i.e. president who wields power for a fixed term of five years. After that, people elect president through Electoral College (Ibid).

\section{6) Union of States}

7) Article 1 of the constitution declares that India is a union of states. It includes 28 States and 7 Union Territories (Ibid: P.13).

\section{8) Federal System with Unitary Bias}

Indian constitution described India as a union of states (Article 1) of the Constitution which implies that Indian federation is not the result of any agreement among the units and the units cannot secede from it. (Choudhry, Khosla, and Meheta,2016: P.540).

\section{9) Rigidity and Flexibility}

India's constitution is both rigid and flexible. Some of its provisions can be amended in a difficult way while others very easily by passing a simple law. According to article 368 of the constitution it encompasses partly rigid and partly flexible provisions (Mellalli, 2015, P.13).

\section{0) Provision of Fundamental Rights and Duties}

Under part III Articles 12-35, the constitution of India grants and guarantees fundamental rights to all its citizens. It is called Indian Bill of Rights. Initially, 7 
fundamental rights were granted but after the deletion of the right to property from the list of fundamental right (44th amendment act 1979) their number came down to six, (i) Right to Equality (ii) Right to Freedom , (iii) Right against Exploitation, (iv) Right to Freedom of Religion, (v) Cultural and Education Right, (vi) Right to constitutional Remedies (Art.32). Part IV A(article 51A) of the constitution describes the following fundamental Duties of the citizens, (i) Respect for the constitution, the national flag and the national anthem (ii) cherish the noble ideals of the freedom struggle, (iii) Uphold and protect the sovereignty, unity and integrity of India (iv) Defend the country and render national services when called, (v) Promote the common brotherhood of all the people of India and renounce any practice derogatory to the dignity of the women, (vi) Preserve the rich heritage of the nation's composite cultures, (vii) Protect the natural environment and have compassion for living creatures, (viii) Develop scientific temper, humanism and spirit of inquiry and reform, (ix) Safeguard public property and adjure violence, (x) strive for excellence in all individuals and collective activity, and (xi) Duty of the parents to send their children to schools for getting education (Choudhry, Khosla, and Meheta, 2016, P.699)..

\section{1) Provision of National and State Human rights Commission}

With a view to protect human rights of all people the Protection of Human Rights Act, 1993 was passed by the union parliament in link with Indian constitution. Under it the National Human Rights Commission was established. It acts as an independent commission with a status of a civil court for preventing the violation of human rights of people; such commission can be formed at state levels too.

\section{2) Directive Principles of State Policy}

Part IV of the Constitution deals with the Directive principles of state policy and provides one of the most striking features of the Indian constitution (Article 3651). It guides the government while formulating new policy to ensure adequate means of livelihood, fair distribution of wealth, equal pay for equal work, protection of children, women, labour and youth old age pension, social security, local self government, protection of the interests of the weaker sections of society, promotion of cottage industries, rural development, international peace, friendship and cooperation with other states etc.

\section{3) Bicameral Legislature}

Article 79 of Indian constitution provides a bicameral legislature at centre consisting of Rajyasabha (Council of States) and Loksabha (house of the people). The LokSabha 
is the lower, popular, directly elected house of the parliament. Its maximum strength stands fixed at 550 presently lokSabhahs 545 members. The people of each state elect representatives in proportion to their population (Kapur and Mishra, 2012, P.313).

\section{4) Parliamentary System of Government}

Indian Constitution (Article 74) provides a parliamentary system of government, i.e. the real executive power rests with the council of minister and the president is only a nominal ruler for all its policies and decisions the council of minister is collectively responsible before LokSabha. LokSabha can remove the ministry by passing a vote of no confidence. The cabinet in fact, the prime minister has the power to get the LokSabha dissolved by the president. The state parliament also works in the similar basis (Kapur and Mishra, 2012, P.13).

\section{5) Adult Suffrage}

Article 326 of the Constitution provides for universal adult suffrage. All registered men and women above the age of 18 years have the right to vote in elections (Mellalli,2015,P.10).

\section{6) Single Citizenship}

India is the single independent and sovereign integrated state. Presently it has 28 states and 7 Union Territories. All citizens enjoy a common uniform citizenship. They are entitled to equal rights and freedoms, and equal protection of the state (Article 5-11) (Chakrabarty, 2017, P.136).

\section{7) Independent Judiciary}

Indian constitution provides an independent judiciary (Article 76) and ensures that the government is carried on in accordance with the provision of the constitution and acts as a guardian of the liberties and fundamental rights of the citizens of both the union and the states. Indian judiciary has an autonomous organization and the states. It works as an independent and powerful judiciary (Kapur and Mishra, 2012, P.326).

\section{8) Judicial Review}

The power of Judicial Review is incorporated in Articles 226 and 227 of the Indian Constitution insofar as the High Courts are concerned. In regard to the Supreme Court Articles 32 and 136 of the Constitution, the judiciary in India has come to control by judicial review every aspect of governmental and public functions. The constitution is the supreme law of the land. The Supreme Court acts as the guardian, 
protector and interpreter of the constitution, also the guardian of the fundamental rights of the people. For this purpose it exercises the power of judicial review. By it the Supreme Court determines the constitutional validity of all laws made by the legislatures. It can reject any law which is found to be unconstitutional. Indian judiciary has been becoming more active towards the performance of its social obligation through public Interest Litigation system (Ibid).

\section{9) Emergency Provision}

The constitution vests extraordinary powers, known as Emergency powers in the president during emergencies out of armed rebellion or external aggression or due to failure of constitutional machinery in the state (Article 352-360).

\section{0) Special Provision for Minorities}

The constitution makes some special provisions for minorities, schedule castes and tribes by granting them special rights and provisions. It provides reservation of seats in the legislatures for the schedule castes and tribes. The reservation is provided in governmental jobs. The reservation is extended up to 2020 .

\section{1) Provision regarding language}

The constitution lays down special provisions for defining the language of the union, regional language and language of the Supreme Court and high courts. It states, the official language of the union shall be Hindi in Devanagari script. It also provides the continuance of English language. A state legislature can adopt the language of the province as its official language. The constitution recognizes 22 modern Indian languages (Chakrabarty, 2017, P.148).

\section{2) A Consolidation of Several Sources}

During the formulation of the constitution of India, the founding fathers used several sources. Values and ideas of the national movement guided their path. National movement influenced them to adopt secularism as the ideal. Some provisions of government of India Act 1935 were used by them and several features of foreign constitutions influenced them and were adopted.

British Constitutional system influenced parliamentary system and bicameralism. US constitution influenced them to republicanism, independence of judiciary, judicial review and bill of rights. Former USSR socialist revolution of 1917 influenced them to adopt socialism as a goal. Similarly they were influenced by the constitutions of Canada, Australia Germany and Ireland. 


\section{Salient Features of the Constitution of Nepal 2015 (2072)}

Shifting from centuries old monarchy to federal republic, Nepal has finally succeeded to draft and promulgate new constitution through the second term of constituent assembly (CA).

The Interim Constitution of Nepal 2007 (2063), designed for the election of a Constitution Assembly, enabled it to write Nepal's permanent constitution. The new constitution was to be promulgated by May 28, 2010. Due to disagreements among political parties on several issues, the house was not able to do the assigned job. This led to amendment of the term of the house again and again. On May 25, 2011, eventually the supreme court of Nepal ruled that the repeated extension of the interim constitution was not right. It reasoned that an elected house is not supposed to extend its term again an elected house going beyond the reasonable electoral mandate (Naidu, 2016, 138).

On May 28, 2012 the constituent assembly was dissolved and new elections were held on November 19, 2013 to elect the constituent assembly II on a special arrangement agreed by the political parties and approved by the president. The political leaders then pledged to draft a new constitution within a year. The new assembly expressly committed that the new constitution would be promulgated on January 22, 2015. However due to continued differences on key issues including system of governance, judicial system and federation issues like number, name and areas of the provinces to be carved, the constitution could not be finalized and promulgated in time. Ultimately it becomes possible to finalize and adopt the constitution (Naidu, 2016, p.139).

A total of 507 votes were casted in favor of the constitution Bill while 25 votes went against it. Major three political parties, Nepali congress (NC), CPN UML, and UCPN (Maoist) and a majority of fringe parties voted in support of the Bill. Those voting against the Bill were members of Rastriya Prajatantra Party Nepal (RPPN). However, some Terai based parties boycotted the constitution finalization and adoption process. Of the total 598 CA members 532 were at the meeting. The Bill of the new constitution was also accepted with more than a two-third majority on September 16, 2015(Adhikari, 2015).

\section{1) Provision of Preamble}

The preamble has the following features:

i) The constitution has been adopted and announced in the name of 'We the people for Nepal, in exercise of the sovereign power inherent in us',

ii) People of Nepal have sovereign power and right to autonomy and self rules 
by maintaining Nepal' independence, sovereign, geographical integrity, national unity, freedom and unity,

iii) It recalls historical Peoples Movements and reminds struggles and the sacrifice made by people for national interest, democracy and progressive change.

iv) It has recognized martyrs, disappeared citizens and victims of the continued struggle.

v) It declares ending all forms of discriminations and oppression created by feudal, autocratic, centralized and unitary systems of government in the past.

vi) It notes its commitments to Nepal's multiethnic, multilingual multicultural and diverse geographical specificities and end of discriminations relating to class, ethnicity, region, language, religion and gender to protect and promote unity in diversity, social and cultural solidarity, tolerance and harmonious attitudes.

vii) It also expresses determination to create an egalitarian society on the basis of the principle of proportional inclusion and participation to ensure equitable economy, prosperity and social justice.

viii) Commitment on peoples' competitive multiparty democratic governance system, civil liberty, fundamental rights, human rights, adult franchise, periodic elections, complete press freedom and an independent impartial and competent judiciary and the concept of rule of law (Naidu,2016: P.139).

\section{2) Written Constitution}

Nepali constitution has 35 parts, 308 Articles, 9 Schedules and a preamble. It has many new and progressive provisions. It has become somehow lengthy document due to political reason. Due to the distrusts among parties, things have been unnecessarily elaborated. This constitution is not only the constitution of the federation, it is also of all provinces and even of municipalities.

\section{3) Constitution as a Fundamental Law of the Nation}

Article 1 states that this constitution is the fundamental law of Nepal. All laws inconsistent with this constitution shall to the extent of such inconstancy be void. The inconstancy will be declared by the supreme court under article 133 . The constitution also states that it shall be the duty of every person to uphold this constitution. 


\section{4) Nepal as a Secular State}

As provision of Article 4 and $26 \mathrm{Nepal}$ is stated as an independent indivisible, sovereign, secular, inclusive state. Demarcation attached to this provision makes clear that the word 'Secular' as stated above means protection of religion and culture being practiced since ancient times and religious and cultural freedom.

\section{5) Sovereign and state Power to the people}

The system shall be created by people; hence, the sovereignty and state authority of Nepal are vested in her people. Their exercise shall be as provided in this constitution. [Article 2]

\section{6) Provision of Single Citizenship}

Article 11 deals with major citizenship provisions. Nepal constitution has the provision of single citizenship unlike the dual citizenship of US constitution i.e. Federal and state [Article 10 (2)]. In terms of acquisition of citizenship by descent, one must have a Nepali father or mother at the time of his/her birth. [Clauses (1), (2) and (3) of Article 11]. Each child has a guardian though mother/father is unknown. [Clause (5)] If foreign woman married to Nepali citizen and wishes, she may acquire naturalized citizenship of Nepal as provided in a federal law.

\section{7) Provision of Fundamental Rights}

Nepali constitution provides a long list of fundamental rights. [Part III] There is a provision for affirmative action for historically prejudiced or disadvantaged communities among others. [Article 18 (3)] The right to inclusion and participation in the state structure is also there that applies to all communities in the country [Article 42]. The list of the fundamental rights is available from article 16-48 as:

Rights to live with dignity, (16), Right to freedom (17), Right to equality (18), Right to communication (19), Right to justice (20), Right of victim of crime (21), Right against torture (22), Right against preventive detention (23), Right against untouchability and discrimination (24), Right relating to property (25), Right to freedom of religion (26), Right to information (27), Right to privacy (28), Right Against exploration (29) Right to clean environment (30), Right relating to education (31), Right to language and culture (32), Right to employment (33), Right to labor (34), Right relating to health (35), Right relating to food (36), Right of to housing (37), Right of women (38), Rights of the child (39), Right of Dalit (40), Rights of senior citizens (41), Right to social justice (42), Right to 
social security (43), Right of the consumer (44), Rights against exile (45), Rights to constitutional remedy (46), implementation of fundamental rights (47) and Duties of citizens (48) [The constitution of Nepal,(2016:9-26)].

\section{8) Provision of Specific Independent Constitutional Commissions}

Nepali constitution creates specific independent constitutional commission, Dalit Commission, Janajati Commission, Medhesi Commission, Tharu Commission and Muslim Commission. They will exist with the national human rights commission. They are created outside the framework of fundamental rights, in different chapters, and have a mandate to recommend changes in laws, policies, and practices of areas for continuing and protection the fundamental rights (Bhandari, 2016: P.290).

\section{9) Inclusiveness}

Nepali constitution expresses determination of the state to build an equitable society on the basis of the principle of proportional inclusion and participation by ensuring economic equality, prosperity and social justice. It encompasses inclusion through the provision of preamble, fundamental rights, directive principle, political participation power sharing, commissions and political parties (Ibid, 2016, P.278).

\section{0) Provision of Directive Principles and Polices}

The constitution also lays down the directive principles, policies and responsibilities of the state's guidelines for governance. While the policies recommended by the constitutionally stated thematic commissions are based on modern requirements. Chapter 4 deals with long term principles, policies and responsibilities. It is the responsibility of the state to mobilize required resources and means for their implementation [Article 49]. Even though, citizens cannot claim these principles and policies as a matter of right politically, Article 53 requires the government to produce an annual report regarding its works and achievements made in the implementation of these principles, policies and responsibilities.

\section{1) Provision of National Language and Language of the Nation}

Nepali language remains as the official language of Nepal [Articles (6) and (7)]. All the mother tongues spoken in Nepal shall be the national languages (Article 71); a province can select one or more national language spoken by majority of 
the people in that province as the language of official business, as provided by the provincial law. Other matters concerning language shall be as decided by the government on the recommendation of the language commission to be established by the federation government within a year [Article 7]. This commission has been empowered to determine the basis for a language to acquire status of official language and forward a recommendation to the government. It is also to forward a recommendation to the government regarding the measures to be adopted for the protection, promotion and development of languages [Article 287(6)].

\section{2) Three Layers of Federalism}

The constitution restructures Nepal as a federal country with three layers of federalism [Part 5]. The erstwhile unitary structure of the country has been replaced by seven federal provincial and local bodies. There is an elaborate federal scheme in the constitution [Part 5-20]. It provides for separate list of the powers of the federal layers [schedule 5-9]. Similarly, legislative and financial procedures of each level have also been elaborated by the constitution [Parts 14-16 and 18-19]. A national natural resources and fiscal commission has been created to determine extensive grounds and measures, regarding the distribution of revenue from the federation consolidated fund to the federal, provincial and local level governments according to the constitution and law [Articles 250-251]. The demarcation of provincial borders will be finalized by federal commission and provinces will be named through two-third majority in the provincial parliament [Article 295].

To achieve the federal objectives, part 5 of the constitution sets out some key principles. At first, the state powers of Nepal shall be used by three main levels of structure. Federal, provincial and local bodies work in accordance with this constitution. Secondly, the power of each level of the structure has been set out in the given schedules and shall be exercised in accordance with this constitution and the federal law. Then the constitution also sets out concurrent/shared power of the federations and the province, and federation province and the local level (Ibid: P.310).

\section{3) Parliamentary System of Government}

Nepal proceeds a parliamentary system at the federal and provincial levels. Article 74 states that the form of governance of Nepal shall be "multiparty, competitive, federal democratic republican parliamentary system based on plurality" at the federal level, it will have a bi-cameral parliamentary form of government with a president elected through the legislative-parliament and the national assembly as 
well as the provincial legislative body. As provision of Article 105(5) the prime minister will be elected by the legislative-parliament based on majority. There are there important departures from the erstwhile Westminster system. First, the prime minister cannot dissolve the parliament. Second, there can be no notion for vote and no confidence against the prime minister for two years subsequent to his/her election. Third, any no confidence motion moved for the removal of the prime minister in the House of Representative must also come with a proposal for the new prime minister who will immediately replace him/her: "the name of the member proposed for prime minister should be mentioned when tabling the no confidence motion under clause (4)" (Naidu, 2016: P.145).

\section{4) Executive power vested in the Council of Ministers}

The executive powers of the country shall vest in the council of ministers while the president would be constitutional head of the country. Article 66 limits the power of the president to three important categories: (1) President shall exercise his/her rights and duties as provided for by this constitution and federal laws, (2) while exercising rights under clause (1) the president shall perform all the works with the consent and recommendation of the council of ministers, except in case where the works have to be performed expressly under the recommendation of some agency or official. Such consent and recommendation shall be made to the president through the prime minister and (3) the decision or order made in the name of the president as provident for by clause (2) and the certification of credentials in that regard, shall be done as specified by federal law. As an Institutional head, the president is to "promote national unity of Nepal." Similarly the constitution states that' "Compliance and protection of the constitution shall be the min duties of the president" (Ibid, 2016: P.146).

\section{5) Independent of Judiciary with the Provision of Constitutional Bench}

Nepal's constitution reflects, through its preamble multiparty democracy, individual liberty and freedom, fundamental rights, human rights, adult franchise, periodic election, press freedom, rule of law, fair, independent and capable judiciary as basic democratic values of the Nepalese society. According to part 11, the Supreme Court will specialize on constitutional issues by creating provision for a constitutional bench. Five judges will be assigned to this bench. Further, constitutional council will nominate the chief justice and head and members of the constitutional commissions. The judicial council will nominate the judge of the supreme, high and district courts, the judicial system is an integrated one. 
Apart from supreme court, Nepal will have high court in each province and district courts as necessary (Bhandari, 2016, P.278).

\section{6) Mixed System of Election}

In terms of the electoral system, a mixed system has been adopted comprising of the FPTP (First past the Post) and PR (Proportional Representation). The House of Representatives in the federal parliament will consist of 275 members: 165 elected through FPTP and 110 elected through PR. Similarly, the National Assembly will consist of 59 members, 56 elected through federal provinces and 3 nominated by the president (on the advice of the government).

In the federal provinces, the legislature will be unicameral. There will be a total of 550 members in the legislatures of the 7 states $60 \%$ of there are elected through FPTP and $40 \%$ are elected by PR. The chief minister of the state will be elected by the provincial legislature whereas the head of the province will be appointed by the president.

\section{7) Constitutional Provision of Political Parties}

Article 209-72 continues with the provisions on registration and operation of political parties. They are required to register their names under the Election Commission in accordance with the law. The constitution and rules of the political party should be democratic. Political parties should elect the office bearer in the federal and provincial levels at least once in five years and also there should be the provision of proportional participation so as to reflect the diversity of Nepal in the executive committees at various levels of the party.

\section{8) Provision of Emergency Powers}

If a grave emergency arises in regard to the sovereign territorial integrity of Nepal or the security of any part there of war, external aggression, armed rebellion, extreme economic disarray, natural calamity or epidemic, the president may declare or order a state of emergency in respect of the whole of Nepal or of any specified part thereof (Article 273). In such a case, the concerned province may request the government of Nepal to declare a state of emergency to be enforced.

While issuing emergency, the president may suspend the fundamental right stated as part 3. However, some important fundamental rights and the right as constitutional remedy and right to habeas corpus related to Article 46 shall not be suspended during the continuation of a proclamation or order pursuant to this article. In case the petition is filed, the court may arrange the compensation and punish the guilty 
according to federal law. The president may at any time during its continuance revoke the proclamation or order relating to state of emergency (Kharel, 2016: P.42).

\section{9) Provision of Amendment of the Constitution}

Article 274 permits amendment of the constitution except in prejudicial with the self rule of Nepal, sovereignty, territorial integrity and sovereignty vested in people. An amendment proposal may be presented to either house of the federal legislature. The bill so presented shall be published for the perusal of the general public within 30 days of presentation in either house.

20) Separation of Powers and Rule of Law

System of governance influences through the West ministers model and governing powers are allocated among the executive, legislative and judiciary. But the final adjudicating power is entrusted to the judiciary as an apex court which can interpret the constitution

\section{1) Directive Principle Policies and Obligations of the state}

Part 4 Article 49 to 55 includes directive principles policies and obligations of the state. Article 49 states that the directive principles, policies and obligation set in this part shall the guiding principles for the governance of the state. The state shall mobilize or cause to be mobilized, means and resources as required, implementing the principles policies and obligations set forth in this part. Similarly article 50 is related with directive principle and article 51 with the policies of the state. The subclauses of article 51 include policies relating to: national unity and national security, political and governance system of state, to social and cultural transformation, to economy, industry and commerce, agriculture and land reforms, to development. Article 52 indicates the obligations of the state as it shall be the obligations of the state to make Nepal a prosperous and affluent country by protecting and promoting fundamental rights and human rights, pursuing directive principles of the state and gradually implementing policies of the state. (Bhandari, 2016 ,P.283).

According to Article 53, the government of Nepal shall submit an annual report containing the steps taken and achievements made in the implementation or the directive principles, policies and obligations of the state set forth in this part to the president Article 54. There shall be a committee in the federal parliament in order to monitor and evaluate whether the directive principles. Article 55 remarks that no question shall be raised in any court as to whether any matter contained in parts 5 has been implemented or not. 
22) Adult franchise

Article 84(5), 176(5) and 222(5) of the present constitution has guaranteed the universal franchise system. Aforementioned articles have stated that every citizen above the age of 18 is eligible to caste vote for the election of federal, provincial and local level representations.

\section{3) National Flag Anthem and symbol}

According to article 8(2), 9(1) and 9(2) of the constitution the national flag, anthem and national symbol are determined under schedules 1,2 and 3.

\section{4) Provision of Referendum}

Under part 32 Article 275 of the constitution there is a provision of referendum. Clause (1) of article 275 states that a two-third majority of total number of the federal parliament can go for a referendum with respect to any matter of national importance. Under clause (2) it has mentioned about referendum.

\section{Similarities between two Constitutions}

Nepal and India have close proximity with open border and freedom of movement between people. Geographical, historical, economical and socio-cultural factors have shaped Indo-Nepal political settings (Lama, 2016:82). These countries have framed their constitutions in the interval of 65 years through the constituent assembly. Both constitutions encapsulate almost similar basic features. They are committed to socialism based on democratic principles and values including the people's right for competitive multi-party democratic system of governance system, civil liberties, fundamental rights, federal republic, secularism, adult franchise, periodic election, full freedom of the press, and independent impartial competent judiciary and concept of rule of law.

\section{Differences between two Constitutions}

Despite similarities between the two constitutions, there are some substantial differences as well which are as follows.

As constitutional features, Nepal is independent, indivisible, sovereign secular, inclusive, democratic socialism oriented, federal democratic republic state but India stands for sovereign, and socialist, secular, democratic republic state. All mother tongues spoken in Nepal are national languages whereas in India no national language, though official language is Hindi. Single federal citizenship with federal identity is in Nepal but no specific federal identity in India. Sovereignty is inherent in Nepali people 
but in India unclear. Right to recognition in Nepal, explicitly mentioned that women shall have equal rights in ancestral property, but no such provision in India though equality in equal circumstances is mentioned in Article 14. Both the proportional and first past the post system of representation are adopted in Nepal but in India only first past the post system is followed. Provision of constitutional court, independent judiciary with a constitutional court for 10 years is in Nepal and Independent judiciary but not constitutional court in India. Secularism means protection of 'Sanatana Dharma' Cow as National Animal in Nepal and Ban on religious conversion but there are three meanings of Indian Secularism (a) 'Sarv Dharma Sambhava' (b) 'Dharma Nirpekshata' and (c) 'Protection of minority rights'.

The substantial similarities and differences between Nepalese and Indian constitution

\begin{tabular}{|c|c|c|c|}
\hline S.N. & $\begin{array}{l}\text { Contents/ } \\
\text { Features }\end{array}$ & Similarities & Differences \\
\hline 1 & $\begin{array}{l}\text { Nature of the } \\
\text { constitution }\end{array}$ & $\begin{array}{l}\text { Written, democratic, } \\
\text { republic, federal socialist, } \\
\text { secular, rigidity/flexibility. }\end{array}$ & $\begin{array}{l}\text { Indian constitution is the longest in the } \\
\text { world and Nepalese moderate. }\end{array}$ \\
\hline 2 & $\begin{array}{l}\text { System of } \\
\text { governance }\end{array}$ & $\begin{array}{l}\mathrm{P} \text { a r } 1 \text { i a } \mathrm{m} \text { e } \mathrm{n} \text { a } \mathrm{r} \text { y } \\
\text { democratic system of } \\
\text { government. Nepal- } \\
\text { Article } 74 \text { and 105, } \\
\text { India- Article } 74 \text { and } 79 .\end{array}$ & $\begin{array}{l}\text { The form of government in Nepal } \\
\text { is multi-party, competitive, federal } \\
\text { democratic, republican, parliamentary } \\
\text { based on pluralism. Bi-cameral at the } \\
\text { center and unicameral at provincial } \\
\text { level. In India parliamentary form of } \\
\text { government based on West minister } \\
\text { model. Bi-cameral legislature both at the } \\
\text { center and provincial level. }\end{array}$ \\
\hline 3 & $\begin{array}{l}\text { Fundamental } \\
\text { Rights }\end{array}$ & $\begin{array}{l}\text { Nepal-Article 16-46. } \\
\text { India-Article 12-35. }\end{array}$ & $\begin{array}{l}\text { Nepal- property right as a constitutional } \\
\text { right whereas in India legal rights. }\end{array}$ \\
\hline 4 & $\begin{array}{l}\text { Directive } \\
\text { principle and } \\
\text { state policies. }\end{array}$ & $\begin{array}{l}\text { Nepal-Article } 49 \text { to } 55 . \\
\text { India- Article } 36 \text { to } 51 .\end{array}$ & $\begin{array}{l}\text { Nepal-Article } 49 \text { states as the guiding } \\
\text { principles for the governances. India-adopts } \\
\text { them as policy blue prints for future. }\end{array}$ \\
\hline 5 & Citizenship & $\begin{array}{l}\text { Nepal- Article } 10 \text { to } 11 \text {. } \\
\text { India- } 5 \text { to } 11 \text {. Both the } \\
\text { countries adopt single } \\
\text { federal citizenship } \\
\text { provision. }\end{array}$ & $\begin{array}{l}\text { Single citizenship with federal identity } \\
\text { in Nepal and in India, every citizen has } \\
\text { equal right wherever he/she may reside. }\end{array}$ \\
\hline
\end{tabular}




\begin{tabular}{|c|c|c|c|}
\hline 6 & Language & $\begin{array}{l}\text { Nepal- Article } 6,7 \text { and } \\
\text { 287. India- Article } 343 .\end{array}$ & $\begin{array}{l}\text { All mother tongues spoken in Nepal } \\
\text { are National languages but in India no } \\
\text { national language. Hindi is mentioned } \\
\text { in Article } 343 \text { as official language and } \\
\text { English could be used for initial } 10 \\
\text { years. }\end{array}$ \\
\hline 7 & $\begin{array}{l}\text { Executive } \\
\text { powers }\end{array}$ & $\begin{array}{l}\text { Nepal-Article } 66 \text { and } \\
75 . \text { India-Article } 52 \text { and } \\
53 .\end{array}$ & $\begin{array}{l}\text { Article } 75 \text { of the Nepalese constitution- } \\
\text { the executive power is vested in council } \\
\text { of ministers. Article } 53 \text { of the Indian } \\
\text { constitution entrusted to the president. }\end{array}$ \\
\hline 8 & $\begin{array}{c}\text { Independent of } \\
\text { Judiciary and } \\
\text { judicial review }\end{array}$ & $\begin{array}{l}\text { Nepal- Article } 126 \text { to } \\
\text { 161. India- Article 226, } \\
227 \text { and Supreme Court } \\
\text { power Article } 32 \text { and } \\
136 .\end{array}$ & $\begin{array}{l}\text { Independent judiciary with the } \\
\text { constitutional court for } 10 \text { years in } \\
\text { Nepal. India-judicial review is part } \\
\text { of fundamental rights. Nepal has a } \\
\text { provision of judicial council for the } \\
\text { recommendation of the judges of SC. } \\
\text { India-collegiums of judges with no } \\
\text { politics recommend the judges. }\end{array}$ \\
\hline 9 & $\begin{array}{l}\text { Election } \\
\text { System }\end{array}$ & $\begin{array}{l}\text { Adult Franchise with age } \\
\text { of 18. Nepal- in Article } \\
84(5), \quad 176(5), \quad 222(5) . \\
\text { India- Article } 326 .\end{array}$ & $\begin{array}{l}\text { Proportional and single majority system } \\
\text { in Nepal but in India first past the post } \\
\text { system only. }\end{array}$ \\
\hline 10 & Political parties & $\begin{array}{l}\text { Nepal- Article } 269 \text { to } \\
272 . \quad \text { India-based } \\
\text { democratic norms and } \\
\text { values. }\end{array}$ & $\begin{array}{l}\text { Constitution of political parties in Nepal } \\
\text { should be democratic and periodic } \\
\text { conferences for the approval of leadership. } \\
\text { No separate provision in India. }\end{array}$ \\
\hline 11 & $\begin{array}{l}\text { Emergency } \\
\text { powers }\end{array}$ & $\begin{array}{l}\text { Declared by president in } \\
\text { both countries. Nepal- } \\
\text { Article } 273 \text {. India- } \\
\text { Article } 352 \text { to } 365 .\end{array}$ & $\begin{array}{l}\text { If a grave emergency arises, the president may } \\
\text { declare or order a state of emergency partly or } \\
\text { wholly. In India constitutionally categorized; } \\
\text { national, provincial and financial when the } \\
\text { constitutional mechanism is considered } \\
\text { failed. }\end{array}$ \\
\hline 12 & $\begin{array}{l}\text { Amendment } \\
\text { of the } \\
\text { constitution. }\end{array}$ & $\begin{array}{l}\text { Nepal- Article } 274 \text { and } \\
\text { India- Article } 368 .\end{array}$ & $\begin{array}{l}\text { The federal parliament with } 2 / 3 \text { majority } \\
\text { can amend the constitution in Nepal. India } \\
\text { makes amendment with simple majority, } \\
\text { special majority. }\end{array}$ \\
\hline
\end{tabular}




\begin{tabular}{|c|c|l|l|}
\hline 13 & $\begin{array}{c}\text { Inclusiveness } \\
\text { and minority } \\
\text { provision }\end{array}$ & $\begin{array}{l}\text { Special provision for } \\
\text { minorities and schedule } \\
\text { castes, tribes etc }\end{array}$ & $\begin{array}{l}\text { Nepal-proportional representation of } \\
\text { women, geography and population in } \\
\text { all sectors. Right to woman is in wider } \\
\text { sense, at least 33 percent in all sectors } \\
\text { in India narrower sense, no specifically } \\
\text { mentioned. }\end{array}$ \\
\hline 14 & $\begin{array}{l}\text { Provision of } \\
\text { referendum }\end{array}$ & $\begin{array}{l}\text { Nepal- Article 275 } \\
\text { and in India no special } \\
\text { provision. }\end{array}$ & $\begin{array}{l}\text { The federal parliament of Nepal with } \\
2 / 3 \text { majority can hold a referendum } \\
\text { in national issues except sovereignty, } \\
\text { national integrity and national territory. }\end{array}$ \\
\hline $\begin{array}{l}\text { Constitutional } \\
\text { commissions }\end{array}$ & $\begin{array}{l}\text { Nepal- part 21, 22, 23, 23, 26 and 27. India- } \\
\text { article 315,-323 and } \\
325-329 .\end{array}$ & $\begin{array}{l}\text { Commission for the investigation } \\
\text { of abuse of authority, public service } \\
\text { ammission, election commission, } \\
\text { national human rights commission, } \\
\text { national natural resource and fiscal } \\
\text { commission and other commissions but } \\
\text { in India only public service commission } \\
\text { and election commission. }\end{array}$ \\
\hline 16 & $\begin{array}{l}\text { Layers of } \\
\text { federalism }\end{array}$ & $\begin{array}{l}\text { Nepal and India both } \\
\text { have three tiers of } \\
\text { government i.e. federal, } \\
\text { provincial and local. }\end{array}$ & $\begin{array}{l}\text { Nepal with seven states and India with } \\
\text { twenty-eight states. }\end{array}$ \\
\hline
\end{tabular}

\section{Conclusion}

Nepal and India are two neighbors and both countries promulgated their constitutions through popularly elected bodies i.e. Constituent Assembly. Though they have distinct socio-economic, cultural and geographical background, the countries adopted almost similar philosophy while introducing federalism. Nepal introduced parliamentary form of government and independent judiciary. During the constitutional promulgation, the majority of the people of Nepal from all segments of the national population celebrated except some ethnic, Madhesi (plain based) parties with regional roots who were not satisfied with both the process of finalizing the constitution and its final contents. The main comments of the Madhesh based parties have been attributed to the issue of delineation of provinces under the new constitution, the provision on carving out constituencies on the basis of geography and population, representation of provinces both in Lower House and Upper House of the federal parliament, the theme of the proportional representation and certain issues related to new citizenship provisions. 
The awful concern between Madhesh oriented parties created a situation in Nepal. Ultimately, the Madhesh based political forces came in consensus and local and general elections were thereafter held in 2017.

Federalism, republicanism, secularism and inclusiveness are the major attributes of the constitution of Nepal. It stands as the first national constitutional charter in South Asia to include explicit mandate of one-third representation to women in legislative apparatus. The charter institutes fair corpus of provision for language as recognizing all the languages given by the mother to be national languages. The provision related to fundamental rights embodied under part III (Article 16-48) of the Nepalese Constitution are progressive in nature. For instance, right to information, right to communication, right to justice, right to victim of crime, right against torture, right to free legal aid, right to privacy, right to property, right to clean environment, right to language and culture, rights to women, rights of Dalits, rights of senior citizens, right to social security are the progressive provisions in one way. Constituency delineation on the basis of population and geography and flexible constitution amendment procedure are other shining dimensions of the Nepalese constitution.

Provision of independent and impartial judiciary, equitable constituency delineations are the imitating characters of Indian constitution. The strengthening of democratic credentials, social development, and priority of a country depend upon the consolidation of complete justice, independent judiciary and rule of law. It can be possible from the free and fair appointment of the judges of the courts which we can observe in India by both constitutionally and empirically. Nepal also could adopt collegiums system for the appointment of the judges of supreme court- just like India- to negate the influence of the government of the day in judicature.

In conclusion, there seem some more liberal/democratic provisions in Indian constitution, to recruit Supreme Court judges, whereas, Nepal's 2015 Constitution has enormously guaranteed, post modern democratic values: inclusive democracy. 


\section{References}

Acharya, B. (2008). Fundamental Rights in the World Constitutions.Kathmandu :PairaviPrakathan.

Adhikari B (2015). Salient Features of the Constitution of Nepal 2015 (2072). Online Article

Bhandari, S. (2016).Constitutional design and implementation dynamics: Federation and inclusive national building in Nepal. Kathmandu: Himal innovative development and research.

Chakrabarty, B.(2017). Indian Constitution.New Delhi: Sage Publication.

Chaudhary, S., Khosla, M. and Meheta,P.B. (2016).The oxford Handbook of the Indian Constitution. New Delhi: Oxford University Press.

Ghai, K. (2018). Constitution of India 26 Salient Features of the constitution of India.

Grimm, D. (2017). Constitutionalism: Past, Present and Future. United Kingdom: Oxford University Press.

Kapur, A.C. and Mishra, K.K. (2012).Select Constitutions. New Delhi: S. Chand and company ltd.

Kharel, L.P. (2016). Constitutional Law and Comparative Nepalese Constitution. Kathmandu: PairaviPrakashan.

Kochar, G. and Jaiswal,P. (2016). Unique Asian Triangle: India, China and Nepal. New Delhi: M G.B. Books.

Lama, (2016). p.82

Law, J. (ed.). (2015).Oxford Dictionary of Law. London: Oxford University press.

Mclean, I. and Mcmillans, A. (ed.). (2009).Oxford Concise Dictionary of Politics. New York: Oxford University press.

Mellalli, P.(2015). Constitution of India, Professional Ethics and Human Rights.New Delhi: Sage Publication.

Naidu, S.K. (2016).Consitutional Building in Nepal. New Delhi: Gaurav Book Centre Pvt.Ltd.

Pollard, A. (1923)." Lord Bryce and Modern Democracies". History, 7(28), new series, 256-265. Retrieved from http://www.jstor.org/stable/24399968

Strong, C.F. (1973). Modern Political Constitutions (8th Ed.), London: Sidgwickadn Jackson Ltd.

The Constitution of India (Forty-second Amendment) Act-1976: New Delhi.

The Constitution of Nepal (fourth Edition).( 2016), Kathmandu 